\title{
Graduates' Unemployment and Associated Factors in Ethiopia: Analysis of Higher Education Graduates' Perspectives
}

\author{
Mesfin Molla Demissie $\left(\mathbb{D},{ }^{1}\right.$ Adane Hailu Herut ${ }^{(D)},{ }^{2}$ Berhanu Mekonnen Yimer $\left(\mathbb{D},{ }^{3}\right.$ \\ Misganu Legesse Bareke $\left(\mathbb{C}^{1},{ }^{1}\right.$ Birhanu Haile Agezew $\left(\mathbb{1},{ }^{1}\right.$ Negash Haile Dedho $\mathbb{1}{ }^{4}$ \\ and Mulugeta Fufa Lebeta $\oplus^{2}$ \\ ${ }^{1}$ Department of Educational Planning \& Management, Dilla University, Dila, Ethiopia \\ ${ }^{2}$ Centre for Education Research, Dilla University, Dila, Ethiopia \\ ${ }^{3}$ Department of Curriculum \& Instructional Supervision, Dilla University, Dila, Ethiopia \\ ${ }^{4}$ Department of Economics, Dilla University, Dila, Ethiopia
}

Correspondence should be addressed to Mesfin Molla Demissie; mesfinmollademissie@gmail.com

Received 30 September 2021; Revised 23 November 2021; Accepted 25 November 2021; Published 9 December 2021

Academic Editor: Xiao-Guang Yue

Copyright (C) 2021 Mesfin Molla Demissie et al. This is an open access article distributed under the Creative Commons Attribution License, which permits unrestricted use, distribution, and reproduction in any medium, provided the original work is properly cited.

\begin{abstract}
Higher education institutions are responsible for providing their graduates with relevant job skills that will allow them to compete in the labour market. With this in mind, the purpose of this study was to identify the factors associated with graduate unemployment in Ethiopia. The data were collected, analysed, and interpreted using a quantitative design. Using Cochran's sampling formula, 359 graduates from five regions were selected as the sources of primary data. Multinomial logistic regression was used to analyse the data because it is a good model for computing the interaction between more than two independent and dependent variables. Cronbach's alpha coefficient of 0.947 indicated that the instrument's reliability is adequate. The study revealed that the independent variables that correlate with graduates' unemployment are demographic characteristics, curriculum, institutional characteristics, graduate characteristics, and economic and labour market conditions. These findings imply that HEIs and governance bodies should reconsider the sector's policy and strategic directions in terms of graduates' employability output. As one of the major improvements, the study also recommends creating an enabling environment for employers to thrive, while higher education institutions adjust their curricula to meet the needs of employers.
\end{abstract}

\section{Introduction}

Graduate employment is perceived as a result of broad categories of educational attainment to assess graduates' educational backgrounds. This may help establish the value of education in general or improve a graduate's performance in particular. However, studies show that various aspects of higher education and related issues have an impact on employment [1-3]. It was also asserted that most of the higher education graduates around the world face unfavourable employment prospects due to a variety of factors such as higher education institution performance, dynamic technological changes, and a crisis in the conception of work in highly developed societies [3].
For many individuals, higher education is necessary for success in the world of work in terms of economic and health benefits, civic involvement, personal development, better communication, realisation of passion, a greater sense of discipline, and a sense of accomplishment [2,4]. This can be accomplished by standardising higher education programs and implementing periodic reforms [5]. In this changing world, where uncertainty is increasing, all higher education institutions should provide positive responses to citizens' social and economic needs. Experiences have shown that higher education institutions can provide the best services to the community if they are concerned about continuous quality, equity, and efficiency improvements $[6,7]$. 
In most developed countries, one of the most important indicators of the performance of higher education institutions is the match between the qualifications obtained by graduates and their employment status [8]. In Europe, for example, one of the main issues associated with competence development and graduate employability identified in the review is the (mis)match between university graduates' competencies and employers' needs. Higher education institutions are concerned with developing strategies to improve graduate employability. Employment and development of graduate skills depend upon a strong sense of innovation and cooperation in higher education throughout the world [9]. In some European countries such as Spain, Germany, and Britain, there are transversal competencies that can be strongly correlated with graduate employability; the expected competencies are (1) communication, with a particular focus on foreign languages [10]; (2) teamwork, considering their relevance for professional practice in all areas of knowledge [11]; and (3) digital competences, which are gaining particular relevance in the context of the labour market [12].

Furthermore, some African countries are in the process of reforming their higher education systems to better match supply and demand in their labour markets. In Senegal, for example, young high-skilled workers experienced a ninepercentage-point employment gain relative to older workers, implying that it is how quality improvements at the university level affect employment [1]. The South African government has also succeeded in shifting the enrolment balance away from humanities subjects and toward science, engineering, and technology, as well as business and economics. Graduates, on the other hand, face disparities in employment outcomes as a result of their educational background, race, and gender [13]. According to scholars such as Calvès and Schoumaker [14], Guarcello et al. [15], Stark and Fan [16], and Getie Ayaneh et al. [17], the high rate of unemployment among young highly educated individuals is due to waiting in queues for formal sector jobs in subSaharan African countries including Ethiopia. If the employment rate of high-skilled workers rises in this situation, it is due to the expansion of the formal sector [13].

In the Ethiopian context, improving the quality and employability of university graduates is one of the goals of the higher education system, which has been assigned a central role in the country's efforts to eradicate poverty $[18,19]$. However, studies found that the labour market is experiencing a shortage of skilled manpower, while the higher education institutions produce dozens of graduates every year [20, 21], implying that many graduates are left without a job for a long time. Regardless of the other causes of these inconveniences, it was discovered that efforts are piecemeal and geared more toward quality assurance than improvement. Researchers strongly argue that the majority of quality concerns, assessment, and review practices appeared to result in little more than formal reporting and were implemented in a haphazard manner [19, 22]. For a developing country, being unemployed for an extended time after graduation has negative consequences in terms of higher education outcomes, implying that higher education is a "wasted investment" $[23,24]$.
Thus, development cannot be ensured solely by producing a large number of graduates; it must also be ensured by paving the way to employment [25], implying that graduate employment can be the backbone of the labour market of developing economies in the twentyfirst century. It is also important to understand that the more the university graduates find job opportunities in their fields of study, the higher the performance of their universities increases. This creates a good match between the supply (a growing number of university graduates) and the demand (job opportunities) of the labour market. To this end, inconvenience behind graduates' employment outcomes and mitigation mechanisms must also be reconsidered for reformative actions. With this argument in mind, this study aims at investigating the factors that cause graduate unemployment from the perspective of graduates of the Ethiopian higher education institutions.

\section{Empirical Literature Review}

2.1. Graduates' Unemployment. Graduates' unemployment is perceived as a falling return on a country's investment in higher education [26]. To be more specific, according to Chan and Tweedie [27], unemployment causes individuals to suffer from financial hardship that impacts families, relationships, and communities. When they happen, consumer spending, which is one of the economy's key drivers of growth, goes down, leading to a recession or even a depression when left unaddressed [28]. Such problems reduce demand, consumption, and purchasing power, resulting in lower profits for businesses and the need for budget cuts and workforce reductions. It creates a cycle that goes on and on that is difficult to reverse without some type of intervention [29]. Persons who face unemployment most often find themselves in long-term earnings losses and complicated psychosocial matters onward [30].

Graduate unemployment is still a global problem. According to the International Labour Organization's annual report, the rate of young graduates entering the labour force is still declining. Similarly, the share of young people who are employed is decreasing. The unemployment rates have remained stable, but they are nonetheless higher than adult unemployment rates between 1999 and 2019 [26, 31]. Countries are meant to share this global burden of unemployment, regardless of their economic circumstances. On the other hand, the share for developing countries may be worse because it exacerbates inequities and causes resentment, which can lead to violence and related behavioural disorders [32]. In Haiti, for example, those female youth need special attention because they are more likely than their male peers to be unemployed or inactive, implying that there are gender inequalities [32]. According to Banks [33], high rates of youth unemployment in Tanzania provide major barriers to young people's capacity to become self-sufficient, which is a critical initial step in the transition to adulthood. It was also noted that one of the effects of graduates' unemployment in Ethiopia is the low self-esteem of individuals [21]. 
Given the rapid expansion of higher education institutions in Ethiopia, enhancing graduates' employability has become a top priority. However, the unemployment rate for 2020 is even $2.79 \%$, a $0.75 \%$ increase from 2019 , while the number of graduates is increasing year after year [34]. This is because of significant disparities between/within public universities and a growing number of smaller for-profit private providers, many of which are said to be of questionable quality [35]. As a result, creating jobs for the growing number of graduates is a major challenge for the country, which is becoming a major concern in the labour market [36].

\subsection{Factors behind Graduates' Unemployment. University} graduates used to invest their time and money to get employed as per their study field. If they remain unsuccessful in their job search for a while, they are meant to be unemployed for several factors. Empirical research findings confirmed the following factors influence the unemployment rate among higher education graduates.

2.2.1. Demographic Characteristics. According to a Mazzotta research, graduates from low-income families have a harder time finding work than graduates from high-income families, and this is especially true in the south of Italy. In the north, male graduates with talent are preferred over female graduates [37]. Meanwhile, in Israel, gender inequalities in employment continue to exist, with women rejecting positions more readily than men due to job content, working conditions, conflicts between work and family commitments, and masculine-typed work. Men spend more time per week looking for work than women [38]. Furthermore, Israelis have first-hand experience with age-related aspects of graduate unemployment, with middle-aged unemployed people reporting spending more time hunting for work than younger people $[38,39]$.

2.2.2. Graduates' Characteristics. Graduate qualities are intended to be influencing variables in Bangladesh graduate unemployment. Academic achievement, technical skills, communication skills, personality, leadership and motivating abilities, and teamwork and problem-solving skills are regarded as independent variables that influence the unemployment rates, according to Hosain et al. [40]. After a thorough statistical analysis, the findings revealed that all independent factors, except for technical abilities and leadership and motivational skills, have a substantial impact on the country's unemployment rate. Another Malaysian study found that people with good employability skills do better than those who lack these skills [41-43].

\subsubsection{Institutional Characteristics. The lack of collaborative} networks between higher education institutions and hiring employers is one of the causes contributing to the growth in graduate unemployment in Nigeria. According to Olukayode's study, there was no meaningful partnership between universities and labor companies in delivering the necessary skills for university graduates' employability and job satisfaction [44]. Another concern is that embracing employability as one of the goals of higher education is not being given the attention it deserves. In Portugal, the level of concern varies according to the discipline and kind of institution. Regardless of their differing perspectives on employability, all academics engage in instructional approaches that promote employability development, albeit with different goals [45]. On the contrary, this suggests that an institutional culture that does not prioritise employability as one of higher education's goals contributes to the rising graduate unemployment rate.

2.2.4. Academic Achievement. Individuals are expected to be adequately prepared with the essential skill set and ready to enter the workforce after completing the university system and getting their degree [46]. The Malaysian experience backs up the notion that higher academic accomplishment leads to greater employability among students, and vice versa, for graduates with low academic achievement [47]. Ismail [42], Yu [43], and Graham and Mlatsheni [41] all support the idea that academic achievement influences graduate unemployment rates, implying that poor command of the English language and a lack of leadership and technical skills have had a significant impact on graduates' unemployment thus far.

2.2.5. Higher Education Curriculum. It was suggested that the higher education curriculum has an impact on the employability outcomes of graduates. According to a study from Lebanese, many universities are assessing students' learning outcomes in relation to academic and career goals, structured materials, and skill development. It also reveals that high-quality higher education, especially with a focus on soft skills and internships, improves graduates' chances of landing their first job following graduation [48]. In some cases, duplication of courses in institutions with less demand may produce graduates with similar courses that are not needed at all regarding higher education curriculum $[32,49]$. Furthermore, because their curriculum must be sensitive to labour market needs, Portuguese institutions acknowledged graduate employability as one of their economic goals [45].

2.2.6. Methods of Teaching and Learning. Higher education teaching methods are considered one of the elements that influence graduates' employability outcomes. According to the findings of a study conducted in Malaysia, some university lecturers attempted to integrate work-related generic skills into their teaching methods [50]. Beyond work-integrated learning, blending traditional small-group teaching activities with work-integrated learning can help bridge the gap between graduates' abilities and labor market demands in the UK [51]. This was confirmed by a recent study that poor teaching-learning environments, a lack of industryskilled staff, and an over-reliance on theoretical content education are considered some of the reasons that affect graduate unemployment in Nigeria [52]. 
2.2.7. Economic and Labour Market Conditions. The rapid expansion of university enrolment, according to Nigerian experience, increases the supply of educated and qualified graduates, which is more than the need for skilled labour in an economy. The ability of a country's economy to absorb a large number of graduates has an enabling surface for the increase of employability performance within the higher education institutions [53]. According to the Russian interregional comparative study, the rate of unemployment is influenced by the structure of employment, the level of economic development of the region, and the demographic structure of a given country [54]. The same may be said about Zambian graduates, as the economic crisis was a key contributory element in youth unemployment in Harare [55]. As a result, if graduates lose their jobs, they are more exposed to poor economic situations because they have already spent their resources pursuing higher education [56].

2.2.8. Global and Emerging Issues. Alike, unemployment is a global problem; graduate unemployment is also influenced by global issues. To begin with the very recent issue, COVID19 is one global burden that influences the rate of graduate unemployment. According to a recent study, the COVID-19 cases cause unemployment in Germany, Italy, and the UK. It was also evident that the pandemic increases the unemployment rate robustly in the mostly European economies [57]. As one of the global factors, climate change, and epidemic diseases are considered as one of the influencing factors of unemployment [58, 59]. Moreover, emerging technologies such as automation systems also influence unemployment as they convert activities from a manual system to a machine system [60]. Furthermore, in 15 out of the 21 countries, one cannot reject that the same natural rate, as a function of the global factor, appears in both the unemployment and inflation equations. In explaining unemployment, the global factor is highly significant, suggesting that models which ignore the global dimension are likely to be deficient [61].

\section{Methodology}

This study used a purely quantitative approach and is based on primary data collected from graduates who received bachelor's degrees from various universities across the country within the last 20 years. The use of a quantitative approach is important because it allows researchers to test hypotheses, examine cause, affect relationships, and make predictions [62]. The respondents were chosen based on multiple characteristics such as age, gender, family background, rural/urban dichotomy, the university they graduated from, year of graduation, their field of study, and employment status of the graduates from five regions of the country: Addis Abeba, Amhara, Oromia, Sidama, and SNNP regional states. Therefore, it can be fair to conclude that the representativeness of the study and the sample size, as shown in Table 1 , is sufficient.
TABLE 1: Demographic characteristics of the respondents.

\begin{tabular}{|c|c|c|c|}
\hline \multicolumn{2}{|c|}{ Characteristics } & $N$ & $\%$ \\
\hline \multirow{3}{*}{ Employment status } & Fully employed & 113 & 31.48 \\
\hline & Underemployed & 57 & 15.88 \\
\hline & Unemployed & 189 & 52.65 \\
\hline \multirow{4}{*}{ Year of graduation } & $2001-2005$ & 6 & 1.67 \\
\hline & $2006-2010$ & 17 & 4.74 \\
\hline & 2011-2015 & 43 & 11.98 \\
\hline & 2016-2020 & 293 & 81.62 \\
\hline \multirow{2}{*}{ Residence } & Rural & 241 & 67.13 \\
\hline & Urban & 118 & 32.87 \\
\hline \multirow{5}{*}{ Region } & Addis Ababa & 58 & 16.16 \\
\hline & Amhara & 81 & 22.56 \\
\hline & Oromia & 124 & 34.54 \\
\hline & Sidama & 69 & 19.22 \\
\hline & SNNPR & 27 & 7.52 \\
\hline \multirow{5}{*}{ Age } & $21-25$ & 157 & 43.73 \\
\hline & $26-30$ & 110 & 30.64 \\
\hline & $31-35$ & 53 & 14.76 \\
\hline & $36-40$ & 19 & 5.29 \\
\hline & $>40$ & 20 & 5.57 \\
\hline \multirow{4}{*}{ Family education } & Uneducated & 123 & 34.26 \\
\hline & Primary education & 17 & 4.74 \\
\hline & Secondary education & 94 & 26.18 \\
\hline & Higher education & 125 & 34.82 \\
\hline \multirow{4}{*}{ Family occupation } & Government employee & 106 & 29.53 \\
\hline & Business owner & 78 & 21.73 \\
\hline & Farmer & 133 & 37.05 \\
\hline & Others & 42 & 11.70 \\
\hline \multirow{2}{*}{ Gender } & Male & 262 & 72.98 \\
\hline & Female & 97 & 27.02 \\
\hline
\end{tabular}

Since the study intended to use the data from a large number of respondents who graduated within the past 20 years, we do not have much information on the exact number of graduates. Using Cochran's formula, the researchers made assumptions that half of the graduates are employed, and the other half are not, which implies $p=0.5$. Now let's say we want $95 \%$ confidence and at least $+5 \%$ precision. A 95\% confidence level gives us a $Z$ value of 1.96 per the normal table. The Cochran [63] formula is as follows:

$$
n_{0}=\frac{Z^{2} p q}{e^{2}}
$$

where $n_{0}$ is the sample size, $z$ is the selected critical value of the desired confidence level, $p$ is the estimated proportion of an attribute that is present in the population, $p q=-1$, and $e$ is the desired level of precision.

This can be calculated as follows:

$$
\begin{aligned}
& p=0.5 \text { and hence, } \\
& q=1-0.5=0.5 \\
& e=0.05 ; z=1.96 \\
& \text { Then, } n_{0}=\left((3.84)(0.5)(0.5) /(0.5)^{2}\right)=384
\end{aligned}
$$

Even though the survey questionnaire was distributed to 384 graduates, 26 of them refused, and 359 questionnaires were collected. Before the distribution of a five-scale Likertbased survey questionnaire to the sample size, a pilot test was 
made for 30 respondents from Sidama regional state to check the quality of the items. Based on the pilot test, Cronbach's alpha coefficient indicated that the reliability is sufficient, which is 0.947. Having confirmed this, the questionnaire was distributed to 384 respondents, 26 of them refused to fill, and 359 questionnaires were collected appropriately.

Regarding the method of data analysis, we used multinomial logistic regression to predict a nominal dependent variable (employment status) given one or more independent variables such as age, gender, residence, academic performance, teaching, learning, institutional characteristics, graduate characteristics, economic and labour market, and global and emerging issues. Indicators were assigned for all of these independent variables. Using the 27 th version of SPSS software, the analysis result of multinomial logistic regression was properly computed and reported at a confidence level of $\alpha=0.05$.

\section{Results and Discussions}

4.1. Results. This section uses both descriptive and inferential statistics to analyse data collected through the questionnaire. This section analyses the data with regard to whether the graduates' unemployment. Table 2 shows the model fitting information of the multinomial regression method.

4.1.1. Model Fitting Information. According to Table 2, the model fitness was assessed using the chi-square statistic. The chi-square value was 124.623 , and the $p$-value was less than 0.05 . This indicates that there is a significant relationship between the dependent variable and the independent variables in the final model.

4.1.2. Goodness-of-Fit. Table 3 presents the goodness-of-fit to ascertain the model that is appropriate for further analyses.

In Table 3, it is shown that the Pearson (729.922) and deviance (578.091) statistics inform us that the model is fit. Since the test is not statistically significant, that is, the $p$-value is greater than 0.05 .

4.1.3. Pseudo R-Square. According to Table 4, the pseudo Rsquare measures for the model are Cox and Snell's (0.308), Nagelkerke's (0.358), and McFadden's (0.186). The model accounts for $18.6 \%$ to $35.8 \%$ of the variance and represents relatively decent-sized effects.

\subsubsection{Likelihood Ration Tests. The likelihood ratio tests are} presented in Table 5.

The likelihood ratio test in Table 5 indicates that the independent predictor variables such as characteristics of the curriculum, graduates' characteristics, economic and labour market conditions, global and emerging issues, age, and gender were significant, which shows that these predictors contribute significantly to the final model.
TABle 2: Model fitting information.

\begin{tabular}{lcccc}
\hline & Model fitting criteria & \multicolumn{3}{c}{ Likelihood ratio tests } \\
& -2 Log likelihood & Chi-square & $d_{f}$ & Sig. \\
\hline Intercept only & 710.334 & & & \\
Final & 585.711 & 124.623 & 20 & 0.000 \\
\hline
\end{tabular}

TABle 3: Goodness-of-fit.

\begin{tabular}{lccc}
\hline \multicolumn{4}{c}{ Goodness-of-fit } \\
\\
\hline Chi-square & $d_{f}$ & Sig. \\
Deviance & 729.922 & 696 & 0.181 \\
\hline
\end{tabular}

Table 4: Pseudo R-square of the model.

\begin{tabular}{lll}
\hline & Pseudo $R$-square & \\
\hline Cox and Snell & 0.308 \\
Nagelkerke & 0.358 \\
McFadden & 0.186 \\
\hline
\end{tabular}

4.1.5. Correlates of Unemployment. Table 5 shows the correlations between the measures of unemployment and a variety of graduates' traits, characteristics of the curriculum, teaching and learning, institutional conditions, graduates' characteristics, economic and labour, market conditions, and global and emerging issues.

According to Table 6, the relationships between unemployment and graduate demographic characteristics $(\beta=-0.404 ; \quad p=0.014, p<0.05) \quad$ and $\quad(\beta=-0.922$; $p=0.000, p<0.05)$ revealed that older graduates have a lower rate of unemployment, while more recent graduates have to wait longer to find a job. This suggests that graduates need to get better information to reduce the search time. Besides, our result showed that higher levels of underemployment were male graduates $(\beta=1.093$; $p=0.006, p<0.05)$. On the other hand, The results of the multinomial regression analysis $(\beta=-0.263$; $p=0.171, p>0.05)$ and $(\beta=-0.182 ; p=0.209, p>0.05)$ in the table, on the other hand, showed that respondents' cumulative grade point average (CGPA) was not associated with whether respondents were jobless or underemployed.

The measures of unemployment were related to the nature of the curriculum $(\beta=-0.058 ; p=0.005 ; p<0.05)$, characteristics of the institutions $(\beta=-0.022$; $p=0.048, p<0.05)$, graduates' characteristics $(\beta=0.055$; $p=0.004, p<0.05)$, and economic and labour market condition $(\beta=-0.062 ; p=0.010, p<0.05)$. Finally, on the other hand, the levels of unemployment were not related to the teaching-learning process $(\beta=0.015$; $p=0.577, p>0.05)$ and global and emerging issues $(\beta=-0.032 ; p=0.121, p>0.05)$.

4.2. Discussions. The aim of this study was to investigate factors linked to graduate unemployment in Ethiopia from the perspective of graduates. According to the study's empirical literature evaluation, there are independent variables that are associated with graduates' unemployment. They are 
TABLE 5: Likelihood ratio tests.

\begin{tabular}{|c|c|c|c|c|}
\hline \multirow{2}{*}{ Effect } & \multirow{2}{*}{$\begin{array}{c}\text { Model fitting criteria } \\
-2 \log \text { likelihood of reduced model }\end{array}$} & \multicolumn{3}{|c|}{ Likelihood ratio tests } \\
\hline & & Chi-square & $d_{f}$ & Sig. \\
\hline Intercept & $585.711^{\mathrm{a}}$ & 0.000 & 0 & - \\
\hline Age & 643.199 & 57.489 & 2 & 0.000 \\
\hline Gender & 593.149 & 7.438 & 2 & 0.024 \\
\hline Commutative grade point of average & 588.427 & 2.717 & 2 & 0.257 \\
\hline Characteristics of the curriculum & 593.543 & 7.833 & 2 & 0.020 \\
\hline Teaching and learning processes & 586.743 & 1.033 & 2 & 0.597 \\
\hline Institutional characteristics & 588.897 & 3.186 & 2 & 0.203 \\
\hline Graduates' characteristics & 592.940 & 7.229 & 2 & 0.027 \\
\hline Economic and labour market & 597.486 & 11.776 & 2 & 0.003 \\
\hline Global and emerging issues & 592.058 & 6.347 & 2 & 0.042 \\
\hline
\end{tabular}

TABLE 6: Correlates of unemployment.

\begin{tabular}{|c|c|c|c|c|c|c|c|c|c|}
\hline \multirow{2}{*}{$\begin{array}{l}\text { Graduates employment } \\
\text { status }\end{array}$} & \multirow{2}{*}{ Variables } & \multirow{2}{*}{$\beta$} & \multirow{2}{*}{ Std. error } & \multirow{2}{*}{ Wald } & \multirow{2}{*}{$d_{f}$} & \multirow{2}{*}{ Sig. } & \multirow{2}{*}{$\operatorname{Exp}(\beta)$} & \multicolumn{2}{|c|}{$\begin{array}{l}\text { 95\% confidence } \\
\text { interval for } \operatorname{Exp}(\beta)\end{array}$} \\
\hline & & & & & & & & $\begin{array}{l}\text { Lower } \\
\text { bound }\end{array}$ & $\begin{array}{l}\text { Upper } \\
\text { bound }\end{array}$ \\
\hline \multirow{10}{*}{ Underemployed } & Intercept & 3.375 & 1.597 & 4.470 & 1 & 0.034 & & & \\
\hline & Cumulative grade point of average & -0.263 & 0.192 & 1.874 & 1 & 0.171 & 0.769 & 0.527 & 1.120 \\
\hline & Gender & 1.093 & 0.401 & 7.438 & 1 & 0.006 & 2.983 & 1.360 & 6.543 \\
\hline & Age & -0.404 & 0.164 & 6.074 & 1 & 0.014 & 0.668 & 0.484 & 0.921 \\
\hline & Characteristics of the curriculum & -0.049 & 0.027 & 3.294 & 1 & 0.070 & 0.952 & 0.903 & 1.004 \\
\hline & Teaching and learning & -0.009 & 0.038 & 0.062 & 1 & 0.804 & 0.991 & 0.920 & 1.067 \\
\hline & Institutional characteristics & 0.005 & 0.015 & 0.108 & 1 & 0.742 & 1.005 & 0.976 & 1.035 \\
\hline & Graduate characteristics & -0.004 & 0.023 & 0.028 & 1 & 0.868 & 0.996 & 0.953 & 1.041 \\
\hline & Economic and labour market & 0.027 & 0.027 & 0.953 & 1 & 0.329 & 1.027 & 0.973 & 1.084 \\
\hline & Global and emerging issues & -0.059 & 0.024 & 5.884 & 1 & 0.015 & 0.943 & 0.899 & 0.989 \\
\hline \multirow{10}{*}{ Unemployed } & Intercept & 6.433 & 1.314 & 23.960 & 1 & 0.000 & & & \\
\hline & Cumulative grade point of average & -0.182 & 0.145 & 1.576 & 1 & 0.209 & 0.834 & 0.627 & 1.108 \\
\hline & Gender & 0.604 & 0.341 & 3.129 & 1 & 0.077 & 1.829 & 0.937 & 3.570 \\
\hline & Age & -0.929 & 0.137 & 45.913 & 1 & 0.000 & 0.395 & 0.302 & 0.517 \\
\hline & Characteristics of the curriculum & -0.058 & 0.021 & 7.898 & 1 & 0.005 & 0.944 & 0.906 & 0.983 \\
\hline & Teaching and learning & 0.015 & 0.028 & 0.311 & 1 & 0.577 & 1.016 & 0.962 & 1.072 \\
\hline & Institutional characteristics & -0.022 & 0.011 & 3.905 & 1 & 0.048 & 0.979 & 0.958 & 1.000 \\
\hline & Graduate characteristics & 0.055 & 0.019 & 8.382 & 1 & 0.004 & 1.057 & 1.018 & 1.097 \\
\hline & Economic and labour market & -0.062 & 0.024 & 6.712 & 1 & 0.010 & 0.940 & 0.897 & 0.985 \\
\hline & Global and emerging issues & -0.032 & 0.021 & 2.399 & 1 & 0.121 & 0.969 & 0.930 & 1.009 \\
\hline
\end{tabular}

${ }^{a}$ Reference category: fully employed.

age and gender, demographics, academic achievement, characteristics of the curriculum, teaching-learning methods, institutional culture, graduate characteristics, economic and labour market conditions, and global and emerging challenges. Using a multinomial logistic regression analysis, the following findings were apparent as associated factors for graduates' unemployment.

In general, the likelihood ratio test demonstrates that both "unemployment" and "underemployment" status in Ethiopia are influenced by demographic characteristics (age and gender), curriculum characteristics, and economic and labor market conditions, all of which contribute to the final model. This means that the aforementioned independent variables have a strong positive correlation with graduates' joblessness. The influence of age as a demographic characteristic is consistent with the finding of [37] that there is an age difference in terms of employment, meaning that young graduates are more likely to compete in the labor market. The findings of Yenew's study support the relationship between graduates' demographic characteristics (age and gender) and their employment status [64]. Second, additional research, such as those in Lebanon and Portugal, has verified the considerable link between these variables and unemployment [45, 48], graduate characteristics in Bangladesh and Malaysia [41-43], and economic and labour market conditions in South Africa and Zambia [53, 55].

In particular, it is reasonable to assume that graduate unemployment is strongly influenced by age, graduate characteristics, curriculum characteristics, institutional characteristics, and economic and labour market conditions in the country. For example, age is highly linked to graduate unemployment, suggesting that the older a person becomes, the more likely they are to become unemployed. In a similar pattern with the likelihood ratio test, the characteristics of 
higher education curriculum, institutional characteristics, and economic and labour market conditions and graduate characteristics are also strongly associated with graduates' unemployment. These occurrences are also confirmed by other studies such as $[32,40,45,49,54,56]$. This implies that working more on the aforementioned influencing factors in higher education institutions has paramount importance. For instance, the development of curriculum content and its major components, as well as their assessment, includes determining the list of training courses/modules, the mastery of which will help form in students the competencies required for successful adaptation to the labour market [65]. As a result, the study suggests that the curriculum designers need to be reconsidered the relevance of curriculum materials. It was also learnt that graduates' knowledge and attitude on what to do and be to get employed are very important aspects of graduates' characteristics.

\section{Conclusions}

The primary source of data for this study was graduate perspectives. The researchers were able to solve issues related to graduates' unemployment and associated factors in the Ethiopian economic context by looking into multiple independent variables. However, more research is needed to cover topics that go beyond the perspectives of graduates, such as employers' opinions, labour market situations, and policy-level difficulties.

The evidence that higher education improves job prospects and earnings potential is overwhelming, and it is influenced by a variety of factors. Identifying the causes of disparities in graduate employment outcomes is critical for higher education institutions' quality, equity, and efficiency. According to the findings of this study, demographic characteristics, curriculum characteristics, institutional culture, graduate characteristics, economic and labour market conditions, and global and emerging issues can all significantly predict the fate of graduates' employment outcomes in Ethiopia. It can be fair to draw a lesson that except for their demographic characteristics, almost all independent variables predict the graduates' employment outcomes. This suggests that the majority of the variables point to the graduating universities' institutional quality and that higher education institutions and governance bodies design flexible and marketable curriculum so that graduates may engage in the dynamic labor market. Higher education institutions must strengthen their inclusive development plans to address the age and gender disparities, as this contributes to the attainment of sustainable development goals. The study also urges governance bodies to create an enabling environment for employers to thrive, while higher education institutions adjust their curricula to meet the needs of employers.

\section{Data Availability}

A set of field data are available from the principal investigator of this project, and it will be shared whenever requested.

\section{Conflicts of Interest}

There are no conflicts of interest.

\section{Acknowledgments}

The authors acknowledge Dilla University for funding this research under the grand theme of "Education and Development in Ethiopia: Existing Realities, Pressing Concerns and Its Implications to Policy Reform." In this regard, our sincere gratitude goes to the Office of Research and dissemination (RDO) and the Office of Vice President for Research and Technology transfer (RTTVP) for facilitating and motivating the research activities.

\section{References}

[1] D. Boccanfuso, A. Larouche, and M. Trandafir, Quality of Higher Education and the Labour Market in Developing Countries: Evidence from an Education Reform in Senegal, The University of Southern Denmark and IZA, Odense, Denmark, 2015, https://ftp.iza.org/dp9099.pdf.

[2] D. F. Harrison, "The role of higher education in the changing world of work," 2017, https://er.educause.edu/articles/2017/ 10/the-role-of-higher-education-in-the-changing-world-ofwork.

[3] U. Teichler, "Graduate employment: challenges for higher education in the twenty-first century," Higher Education in Europe, vol. 22, no. 1, pp. 75-84, 1997.

[4] ViSTA College, "The importance of higher education in the 21st century," 2021, https://www.vistacollege.edu/blog/ resources/higher-education-in-the-21st-century/.

[5] A. John and A. Moyer, "Student debt and perceptions of preparedness for employment or higher education," Journal of Young Investigators, vol. 26, no. 2, pp. 11794-12500, 2014.

[6] A. A. Foroughi Abari, M. H. Yarmohammadian, and J. Toroqi, Effectiveness in Higher Education, Encyclopedia of Higher Education, Ministry of Science, Research, and Technology, Tehran, Iran, 2004.

[7] L. E. Weber, "Justification and methods of university evaluation: a European perspective," 2003, https://www.rieti.go.jp/ jp/events/03022201/pdf/paper/weber.pdf.

[8] E. Corominas, C. Saurina, and E. Villa, "The match between university education and graduate labour market outcomes (education-job match) an analysis of three graduate cohorts in Catalonia," 2010, https://www.aqu.cat.

[9] M. Abelha, S. Fernandes, D. Mesquita, F. Seabra, and A. T. Ferreira-Oliveira, "Graduate employability and competence development in higher education-a systematic literature review using PRISMA," Sustainability, vol. 12, no. 15, p. 5900, 2020.

[10] R. M. Lima, D. Mesquita, C. Rocha, and M. Rabelo, "Defining the industrial and engineering management professional profile: a longitudinal study based on job advertisements," Production, vol. 27, 2017.

[11] M. L. Cruz, G. N. Saunders-Smits, and P. Groen, "Evaluation of competency methods in engineering education: a systematic review," European Journal of Engineering Education, vol. 45, no. 5, pp. 729-757, 2019.

[12] K. Schwab, "The fourth industrial revolution: what it means and how to respond," 2016, https://www.weforum.org/agenda/2016/ 01/the-fourth-industrial-revolution-what-it-means-and-how-torespond/. 
[13] M. Rogan and J. Reynolds, "Schooling inequality, higher education and the labour market: evidence from a graduate tracer study in the Eastern Cape, South Africa," ISER Working Paper No. 2015/3, Institute of Social and Economic Research, Rhodes University, Grahamstown, South Africa, 2015.

[14] A.-E. Calvès and B. Schoumaker, "Deteriorating economic context and changing patterns of youth employment in urban Burkina Faso: 1980-2000," World Development, vol. 32, no. 8, pp. 1341-1354, 2004.

[15] L. Guarcello, I. Kovrova, and F. C. Rosati, "Child labour as a response to shocks: evidence from Cambodian villages," UCW Working Paper, University of Rome, Rome, Italy, 2008.

[16] O. Stark and C. S. Fan, "The effect of international migration on educated unemployment," Immigrants and Their International Money Flows, Upjohn Institute for Employment Research, Kalamazoo, MI, USA, 33-50, 2007.

[17] M. Getie Ayaneh, A. A. Dessie, and A. W. Ayele, "Survival models for the analysis of waiting time to first employment of new graduates: a case of 2018 Debre Markos university graduates, northwest Ethiopia," Education Research International, vol. 2020, Article ID 8877504, 10 pages, 2020.

[18] Ministry of Education, Education Sector Development Program V (ESDP V) 2015/16-2019/20, Minstry of Education, Addis Ababa, Ethiopia, 2015.

[19] T. M. Tadesse, R. M. Gillies, and C. E. Manathunga, "Making sense of quality teaching and learning in higher education in Ethiopia: unfolding existing realities for future promises," 2018, https://ro.uow.edu.au/jutlp/vol15/iss1/4/.

[20] T. Jote, "Exploring employment status and education-job match among engineering graduates in Ethiopia: policy implications," International Journal of African Higher Education, vol. 4, no. 1, 2017.

[21] N. W. Reda and M. T. Gebre-Eyesus, "Graduate unemployment in Ethiopia: the "red flag" and its implications," International Journal of African Higher Education, vol. 5, no. 1, 2019.

[22] M. Nega, "The public-private divide in ethiopian higher education: issues and policy implications," Universal Journal of Educational Research, vol. 5, no. 4, pp. 591-599, 2017.

[23] H. Lauder and K. Mayhew, "Higher education and the labour market: an introduction," Oxford Review of Education, vol. 46, no. 1, pp. 1-9, 2020.

[24] N. G. Mankiw, Macroeconomics, Worth Publishers, New York, NY, USA, 2nd edition, 1994.

[25] G. A. Akalu, "Higher education "massification" and challenges to the professoriate: do academics' conceptions of quality matter?" Quality in Higher Education, vol. 22, no. 3, pp. 260-276, 2016.

[26] International Labour Organisation (ILO), "Global employment trends for youth 2020: technology and the future of jobs," 2020, https://www.ilo.org/wcmsp5/groups/public/--dgreports/---dcomm/---publ/documents/publication/wcms_ 737648.pdf.

[27] S. Chan and D. Tweedie, "Precarious work and reproductive insecurity," Social Alternatives, vol. 34, no. 4, pp. 5-13, 2015.

[28] K. Gousia, A. Baranowska-Rataj, T. Middleton, and O. Nizalova, "The impact of unemployment and non-standard forms of employment on the housing autonomy of young adults," Work, Employment and Society, vol. 35, no. 1, pp. 157-177, 2020.

[29] H. Taye, "Enhancing graduate employability for enhancing the role of higher education in poverty reduction: a gap analysis study with particular reference to private providers operating in Ethiopia," Journal of Business and Administrative Studies (JBAS), vol. 5, no. 1, pp. 64-88, 2013.

[30] J. M. Nunley, A. Pugh, N. Romero, and R. A. Seals, "The effects of unemployment and underemployment on employment opportunities," ILR Review, vol. 70, no. 3, pp. 642-669, 2016.

[31] The Star, "Unemployed graduates increased by $22.5 \%$ to 202,400 in 2020," 2021, https://www.thestar.com.my/ business/business-news/2021/07/27/unemployed-graduatesincreased-by-225-to-202400-in-2020.

[32] M. Justesen and D. Verner, Factors Impacting Youth Development in Haiti, World Bank Publications, Washington, DC, USA, 2007.

[33] N. Banks, "Youth poverty, employment and livelihoods: social and economic implications of living with insecurity in Arusha, Tanzania," Environment and Urbanization, vol. 28, no. 2, pp. 437-454, 2016.

[34] Microtrends, "Ethiopia unemployment rate 1991-2021. Macrotrends: the long term perspective on markets," 2021, https://www.macrotrends.net/countries/ETH/ethiopia/ unemployment-rate.

[35] World Education Network (WEN), "Education in Ethiopia," 2021, https://wenr.wes.org/2018/11/education-in-ethiopia.

[36] British Council, Universities, Employability and Inclusive Development: Repositioning Higher Education in Ghana, Kenya, Nigeria And South Africa, International Higher Education, 2016, https://www.britishcouncil.org.gh/ programmes/education/internationalising-higher-education/ universities-employability-and-inclusive.

[37] F. Mazzotta, The Effect of Parents' Background on Youth Unemployment Duration, University of Salerno, Salerno, Italy, 2008.

[38] L. Kulik, "The impact of gender and age on attitudes and reactions to unemployment: the Israeli case," Sex Roles, vol. 43, no. 1, pp. 85-104, 2000.

[39] J. Poon, "Relationships between demographic factors and employment prospects of architecture, construction and urban planning graduates," International Journal of Construction Education and Research, vol. 13, no. 2, pp. 83-101, 2016.

[40] M. S. Hosain, M. A. A. Mustafi, and T. Parvin, "Factors affecting the employability of private university graduates: an exploratory study on Bangladeshi employers," PSU Research Review, 2021.

[41] L. Graham and C. Mlatsheni, "Youth unemployment in South Africa: understanding the challenge and working on solutions," South African Child Gauge, vol. 2, pp. 51-59, 2015.

[42] N. A. Ismail, "Graduates' characteristics and unemployment: a study among Malaysian graduates," International Journal of Business and Social Science, vol. 2, no. 16, pp. 94-102, 2011.

[43] D. Yu, "Youth unemployment in South Africa revisited," Development Southern Africa, vol. 30, no. 4, pp. 545-563, 2013.

[44] O. A. Afolabi, "2017, Indigenous emotional intelligence scale: Development and validation," Psychological Thought, vol. 10, no. 1, pp. 138-154, 2017.

[45] C. Sin, O. Tavares, and A. Amaral, "Accepting employability as a purpose of higher education? Academics' perceptions and practices," Studies in Higher Education, vol. 44, no. 6, pp. 920-931, 2019.

[46] Z. P. Kunene, "Transitioning from graduation to employment: unemployed graduate's experiences of finding employment," 2018, https://wiredspace.wits.ac.za/jspui/bitstream/10539/ 26339/2/Final_Research\%20Report_Zinhle_457779.pdf.

[47] F. Tentama and M. H. Abdillah, "Student employability examined from academic achievement and self-concept," 
International Journal of Evaluation and Research in Education (IJERE), vol. 8, no. 2, p. 243, 2019.

[48] D. Nauffal and J. Skulte-Ouaiss, "Quality higher education drives employability in the Middle East," Education and Training, vol. 60, no. 9, pp. 1057-1069, 2018.

[49] J. Heo and L. Xiaohui, "A study on the factors influencing graduates' employment," Asia-Pacific Journal of Convergent Research Interchange, vol. 5, no. 3, 2019.

[50] M. Fahimirad, P. K. Nair, S. S. Kotamjani, M. Mahdinezhad, and J. B. Feng, "Integration and development of employability skills into Malaysian higher education context: review of the literature," International Journal of Higher Education, vol. 8, no. 6, p. 26, 2019.

[51] A. Kornelakis and D. Petrakaki, "Embedding employability skills in UK higher education: between digitalization and marketization," Industry and Higher Education, vol. 34, no. 5, pp. 290-297, 2020.

[52] U. C. Okolie, P. A. Igwe, H. E. Nwosu, B. C. Eneje, and S. Mlanga, "Enhancing graduate employability: why do higher education institutions have problems with teaching generic skills?" Policy Futures in Education, vol. 18, no. 2, pp. 294-313, 2019.

[53] P. S. O. Uddin and O. O. Uddin, "Causes, effects, and solutions to youth unemployment problems in Nigeria," Journal of Emerging Trends in Economics and Management Sciences, vol. 4, no. 4, pp. 397-402, 2013.

[54] T. Blinova, S. Bylina, and V. Rusanovskiy, "Vocational education in the system of determinants of reducing youth unemployment: interregional comparisons," Procedia-Social and Behavioral Sciences, vol. 214, pp. 526-534, 2015.

[55] T. B. Bhebhe, R. K. Bhebhe, and B. S. Bhebhe, "An investigation into the causes of unemployment among youths in the city of Harare," Global Journal of Arts, Humanities and Social Sciences, vol. 4, no. 2, pp. 99-102, 2016.

[56] Y. Hwang, "What is the cause of graduates' unemployment? Focus on individual concerns and perspectives," Journal of Educational Issues, vol. 3, no. 2, p. 1, 2017.

[57] Z. Su, D. McDonnell, J. Wen et al., "Mental health consequences of COVID-19 media coverage: the need for effective crisis communication practices," Globalization and Health, vol. 17, no. 1, pp. 1-8, 2021.

[58] M. H. Babiker and R. S. Eckaus, "Unemployment effects of climate policy," Environmental Science \& Policy, vol. 10, no. 78, pp. 600-609, 2007.

[59] A. Lee and J. Cho, “The impact of epidemics on labor market: identifying victims of the Middle East respiratory syndrome in the Korean labor market," International Journal for Equity in Health, vol. 15, no. 1, 2016.

[60] Y. Lima, C. E. Barbosa, H. S. Dos Santos, and J. M. De Souza, "Understanding technological unemployment: a review of causes, consequences, and solutions," Societies, vol. 11, no. 2, p. 50, 2021.

[61] R. P. Smith and G. Zoega, "Global factors, unemployment adjustment and the natural rate," SSRN Electronic Journal, vol. 2, 2007.

[62] J. D. Smith and M. Hasan, "Quantitative approaches for the evaluation of implementation research studies," Psychiatry Research, vol. 283, Article ID 112521, 2020.

[63] W. G. Cochran, Sampling Techniques, John Wiley \& Sons, New York, NY, USA, 3rd edition, 1977.
[64] Y. Alemu Mihret, "Factors associated with women unemployment in Ethiopia," International Journal of Theoretical and Applied Mathematics, vol. 5, no. 5, pp. 68-73, 2019.

[65] E. A. Khodyreva, J. Cai, V. T. Youngblood, and A. N. Khuziakhmetov, "Higher education curricula designing on the basis of the regional labour market demands," EURASIA Journal of Mathematics, Science and Technology Education, vol. 13, no. 7, 2017. 